\title{
Trifluoroacetic acid catalyzed dibenzodiazocine synthesis: optimization and mechanism study
}

\author{
Na Zhao, Li Qiu, Xiao Wang, Jianzhong Li, Yi Jiang, Xiaobo Wan* \\ Qingdao Institute of Bioenergy \& Bioprocess Technology, Chinese Academy of Sciences, 189 Songling Road, Qingdao, Shandong Province 266101, China
}

\section{A R T I C L E I N F O}

\section{Article history:}

Received 26 June 2012

Received in revised form 29 August 2012

Accepted 11 September 2012

Available online 20 September 2012

\begin{abstract}
A B S T R A C T
Dibenzo[ $b, f][1,5]$ diazocines, a class of potential building blocks for novel electrochemical actuators, were synthesized via a novel, efficient acid-catalyzed reaction of 2-acylbenzoisocyanate at room temperature. Real-time NMR analysis and the captured intermediate showed the mechanism was an unprecedented cyclization of the isocyanate with the neighboring acyl group, followed by the dimerization.
\end{abstract}

(c) 2012 Elsevier Ltd. All rights reserved.

\section{Introduction}

[ $4 n \pi]$ Annulenes, such as cyclooctatetraenes, are anti-aromatic macrocycles, which adopt a non-planar conformation. Such molecules and their hetero-derivatives have gained much attention since the beginning of this century because these compounds theoretically can undergo a reversible conformational change to a planar conformation upon a two-electron reduction or oxidation. Therefore, they might be used as a hinge in new electroactive materials for actuation. ${ }^{1}$ In the past decade, many syntheses of these compounds, such as cyclooctatetrathiophene, ${ }^{2,3}$ thiepin, ${ }^{4}$ and azepine $^{5}$ and their applications in electrochemical active polymeric materials have been reported. [1,5]Diazocine also falls into such a compound category since it has $8 \pi$ electrons in its macrocycle and could be reduced to a $10 \pi$ electrons anion ${ }^{6}$ (Scheme 1 ). Indeed, dibenzo[ $b f][1,5]$ diazocine has found its niche in polysulfones ${ }^{7,8}$ as a co-monomer, which enhanced the thermal stability and mechanical properties of the resulting polymer. The preliminary result of its reversible conformation change during electrochemical redox process was also reported. ${ }^{7}$ Furthermore, the derivatives of [1,5] diazocines are a class of useful synthetic building blocks for biomimetic molecular recognition and supramolecular structures. ${ }^{9}$ However, most of the synthetic strategies toward dibenzo[ $b f][1,5]$ diazocines were limited to the condensation reactions of 2aminobenzophenone derivatives, ${ }^{10-12}$ which required water removal techniques, needed long reflux time, and suffered from the tedious preparation steps of the corresponding precursors. ${ }^{13}$ It was reported that the Friedel-Crafts intermediate of 2-isocyanatobenzoyl chlorides could be trapped by 2aminobenzophenone, which further reacted to afford anils,

\footnotetext{
* Corresponding author. Tel./fax: +86 532 80662740; e-mail address: wanxb@ qibebt.ac.cn (X. Wan).
}

together with benzo[ $b f][1,5]$ diazocines in moderate yield. ${ }^{14,15}$ Excess of $\mathrm{AlCl}_{3}$ was needed for this reaction. Recently, Jung et al. improved the condensation method. Dibenzo[ $b, f][1,5]$ diazocines were synthesized in the presence of 0.5 equiv of diphenyl phosphate (DPP) under microwave irradiation in a high yield and this method could afford the desired product within a short time. ${ }^{16}$ There are also some other methods for the synthesis of dibenzo $[b, f][1,5]$ diazocines, but the yields are fairly low. ${ }^{17,18}$ Thus, the potential applications and the limitations of the current synthetic methods to prepare [1,5]diazocines make the development of new synthetic methodology attractive.

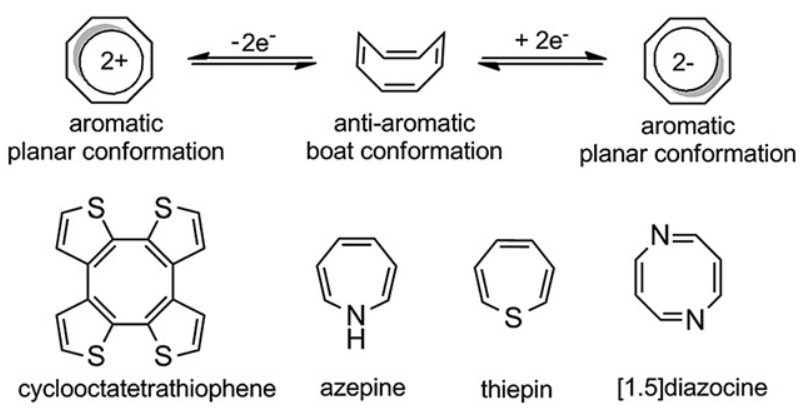

Scheme 1. Anti-aromatic compounds that could undergo reversible conformational changes upon reduction or oxidation.

Recently, we developed a new method for the synthesis of dibenzo[ $b, f][1,5]$ diazocine, in which the water removal technique was replaced by the release of $\mathrm{CO}_{2}$ to construct the imine bond in the diazocine ring. Therefore, the diazocine synthesis was much faster and more efficient. ${ }^{19}$ However, this reaction was conducted using an organic acid as the solvent, which is relatively harsh. Moreover, although we postulated, at that time, that the mechanism involved an acid promoted intermolecular $[2+2]$ cyclization 
between an isocyanate and a ketone moiety, we did not have a solid proof for it. We wish to report here the optimization of the reaction, in which we use milder conditions by employing a catalytic amount of acid, and in addition the clarification of the mechanism of this reaction.

\section{Results and discussion}

\subsection{Attempts to validate the $[2+2]$ cyclization hypothesis}

The previously reported diazocine synthesis by our group was a tandem reaction of 2-benzoylbenzoyl azide 1 at $80{ }^{\circ} \mathrm{C}$ in anhydrous acids, such as acetic acid (AcOH) or trifluoroacetic acid (TFA). The first step in no doubt involved a Curtius rearrangement, but the mechanism of the following transformation remained unclear. It showed some similarity with the $[2+2]$ cyclization reactions between isocyanates and ketones reported in the literature, in that the release of $\mathrm{CO}_{2}$ was observed in both cases. ${ }^{20-22} \mathrm{~A}$ mechanism was proposed accordingly, as shown in Scheme $2 \mathrm{a} .{ }^{19}$ The temperature for the diazocine synthesis was, however, much lower than that reported in the literature (generally above $150{ }^{\circ} \mathrm{C}$ ) for the [2+2] cyclization. If the proposed mechanism was correct, this method would have the potential to become a more general strategy for imine bond construction.

We then examined whether this reaction could be expanded to simple ketones and isocyanates. Unfortunately, when the same conditions were applied to the reaction between benzoyl azide 4 and benzophenone, no imine bond formation was observed, as shown in Scheme 2b. 1,3-Diphenylurea was obtained instead, which was the product of isocyanatobenzene generated in situ. Other substrates, such as benzaldehyde and DMF, which were the more reactive and known to react with isocyanatobenzene at higher temperature, ${ }^{20,22}$ also failed to form the imine bond with compound 4. These results casted a heavy doubt on the mechanism we proposed before: either the diazocine was obtained via a different intermediate rather than the four-membered 1,3-oxazetidin2-one, or there was a specific spatial arrangement requirement of ketone and isocyanate moieties for the $[2+2]$ cyclization to occur. Further investigation was needed to clarify the mechanism.

\subsection{Optimization of the reaction conditions}

Since the first step of the tandem diazocine synthesis was the Curtius rearrangement, we tried to conduct the reaction stepwise to see whether any other intermediate could be isolated. Hence, the corresponding isocyanate $\mathbf{2}$ was obtained in almost quantitative yield when 2-benzoylbenzoyl azide $\mathbf{1}$ was stirred in anhydrous toluene at $80{ }^{\circ} \mathrm{C}$ for $4 \mathrm{~h}$. This intermediate was relatively stable under neutral conditions, but we noticed that it was so sensitive to acids that it was partially converted to diazocine even when we tried to purify it by silica gel chromatography, although in very low yield (Table 1 , entry 1 ).

Table 1

Optimization of the diazocine synthesis

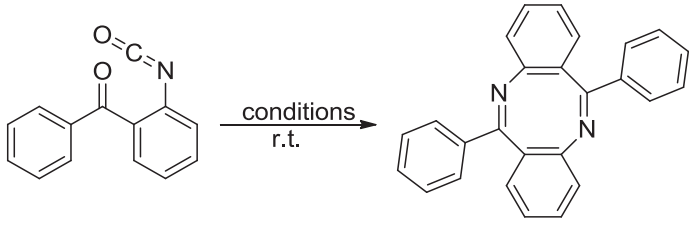

2

\begin{tabular}{llll}
\hline Entry & Acid/solvent & Time $(\mathrm{h})$ & Yield $^{\mathrm{a}}(\%)$ \\
\hline 1 & Silica gel & - & 3 \\
2 & AcOH & 2 & 79 \\
3 & $\mathrm{TFA}$ & 2 & 70 \\
4 & $\mathrm{AcOH}(1$ equiv)/Tol. & 12 & 5 \\
5 & $\mathrm{TFA}(1$ equiv)/Tol. & 2 & 75 \\
6 & $\mathrm{TFA}(0.1$ equiv)/Tol. & 2 & 77 \\
7 & $\mathrm{MeSO}_{3} \mathrm{H}(0.1$ equiv)/Tol. & 12 & 50 \\
8 & $\mathrm{H}_{2} \mathrm{SO}_{4}(0.1$ equiv)/Tol. & 12 & 75 \\
9 & $\mathrm{TiCl}_{4}(0.2$ equiv)/Tol. & 12 & - \\
10 & $\mathrm{BF}_{3} \cdot \mathrm{OEt}_{2}(0.2$ equiv)/Tol. & 12 & 10 \\
11 & $\mathrm{TFA}(0.1$ equiv $) / \mathrm{THF}_{12}$ & 12 & 90 \\
12 & $\mathrm{TFA}(0.1$ equiv$) / \mathrm{MeCN}$ & 12 & 90 \\
13 & $\mathrm{TFA}(0.1$ equiv $) / \mathrm{CHCl}$ & 75 \\
\hline
\end{tabular}

a Isolated yield.

The formation of diazocine on silica gel implied that this reaction could occur under much milder conditions. The reaction temperature was then decreased to room temperature, and the isocyanate still afforded the diazocine both in dry $\mathrm{AcOH}$ and in TFA in good yields (Table 1, entries 2 and 3 ). We then tested whether the reaction could occur in the presence of a catalytic amount of acid. Although using 1.0 equiv of $\mathrm{AcOH}$ was almost ineffective to promote this reaction (Table 1 , entry 4 ), strong acids, such as TFA and $\mathrm{H}_{2} \mathrm{SO}_{4}$ showed good catalysis capability in this reaction (Table 1, entries 5-6 and 8). Methanesulfonic acid could also catalyze this reaction, but resulted in lower yield (Table 1, entry 7). Lewis acids, such as $\mathrm{TiCl}_{4}$ and $\mathrm{BF}_{3} \cdot \mathrm{OEt}_{2}$ were not able to catalyze this reaction efficiently (Table 1, entries 9-10). TFA was then chosen as the best catalyst for this reaction. Switching the solvent to THF or MeCN gave the best yield of diazocine, but longer reaction time was necessary.

a) Previously Proposed Mechanism

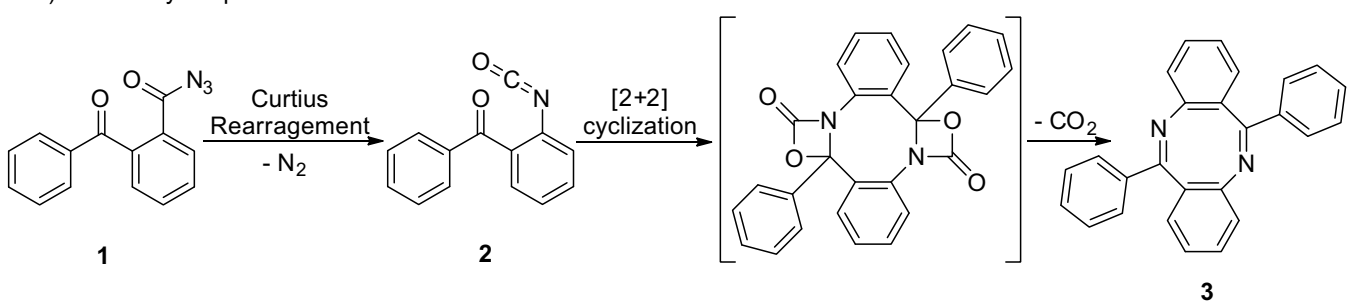

b) Attempts to Verify the [2+2] Mechanism
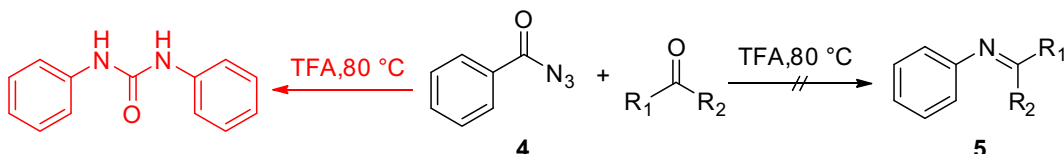

$\begin{array}{ll}\mathrm{R}_{1}=\mathrm{Ph}, & \mathrm{R}_{2}=\mathrm{Ph} \\ \mathrm{R}_{1}=\mathrm{Ph}, & \mathrm{R}_{2}=\mathrm{H}\end{array}$

$\begin{array}{ll}\mathrm{R}_{1}=\mathrm{Ph}, & \mathrm{R}_{2}=\mathrm{H} \\ \mathrm{R}_{1}=\mathrm{NMe}_{2}, \mathrm{R}_{2}=\mathrm{H}\end{array}$

Scheme 2. Previously proposed mechanism and the attempts for validation. 


\subsection{A deeper insight into the mechanism}

Given that all the reported [2+2] cyclizations between isocyanate and ketone require much higher temperature, the cyclization of 2-benzoylphenyl isocyanate at room temperature is highly unlikely to go through the four-membered intermediate (or transition state), which is a highly-strained, high-energy species. There must be another pathway toward the diazocine. Fortunately, the milder conditions and longer reaction time now made tracking the intermediate possible. The reaction was then monitored via the real-time ${ }^{13} \mathrm{C}$ NMR analysis, and the results were shown in Fig. 1 (Full spectra are available in Supplementary data).

Fig. 1a shows the ${ }^{13} \mathrm{C}$ NMR spectrum of 2-benzoylphenyl isocyanate 2 before the addition of TFA, with trace amount of impurities (labeled in $\square$ ) in it. Peaks at $195.5 \mathrm{ppm}$ and $125.2 \mathrm{ppm}$ stand for $C_{(C=O)}$ and $C_{(N C O)}$, respectively. Five min after the addition of a catalytic amount of TFA, the intensity of these two characteristic peaks decreased dramatically to the same intensity level as the impurities, which acted as an 'internal standard', as shown in Fig. 1b. This observation suggested that most of the starting material was consumed at the very early stage of the reaction, but the characteristic peaks of the corresponding diazocine were barely seen. Instead, a distinct peak at $124.9 \mathrm{ppm}$ and broad bumps in the aromatic region appeared, which suggested the presence of a new intermediate. After $1 \mathrm{~h}$, the characteristic peaks of the starting material were totally gone, as shown in Fig. 1c, while the intermediate peaks remained, with the clear appearance of diazocine peaks (for example, peak at $169.7 \mathrm{ppm}$ for $\mathrm{C}_{(\mathrm{C}=\mathrm{N})}$ ). Further monitoring showed that the intensity of the diazocine peaks increased with prolonged reaction time, while the intensity of the intermediate peaks decreased accordingly (see the Supplementary data for details). After $24 \mathrm{~h}$, the intermediate was fully converted to diazocine (Fig. 1d). The broad bumps in the ${ }^{13} \mathrm{C}$ NMR spectra also implied that the intermediate might exist in a very complicated form. Luckily, we were able to trap this intermediate, by adding EtOH to the reaction mixture at the early stage, as shown in Scheme 3, and compound 6 was obtained in $40 \%$ yield. The same product was isolated by Acharya et al., in their attempts to trap the Friedel-Crafts intermediate of 2-isocyanatobenzoyl chlorides. ${ }^{15}$

The isolation of the trapped intermediate $\mathbf{6}$ strongly suggested a completely different mechanism from the previously reported one. It was reasonable to postulate that compound $\mathbf{6}$ was obtained via the nucleophilic attack of EtOH at an electron-deficient intermediate. The intermediate is very possibly 4-phenyl- $2 \mathrm{H}$-benzo

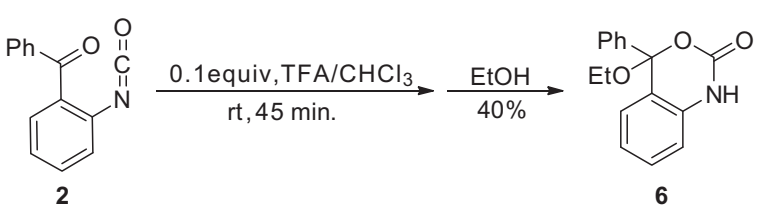

Scheme 3. Capture of the possible intermediate.

[d][1,3] oxazin-2-one 8a, as shown in Scheme 4. TFA might either act just as a Bronsted acid to catalyze the sigmatropic rearrangement of $\mathbf{2}$ to afford 8a (Path A), or add to the isocyanate to form the corresponding carbamic anhydride $7,{ }^{23}$ which, upon the neighboring group participation of the carbonyl group, cyclizes to give the same intermediate (Path B). Although Path A sounded more plausible, we could not fully rule out the possibility of Path B. Although the aromaticity of the benzene ring is lost during this process, the newly formed $2 \mathrm{H}$-1,3-oxazin-2-one is heteroaromatic hence might compensate this loss and make this reaction occur smoothly at room temperature. This step is the fast step. In the presence of acid, compound $\mathbf{8 a}$ might also exist in its protonated form $\mathbf{8 b}$. This might account for that no explicit signal of this intermediate could be observed in the in situ ${ }^{13} \mathrm{C}$ NMR study. The $\alpha, \beta$-unsaturated iminelike $2 H$-[1,3]oxazin-2-one ring is sensitive to nucleophilic attack, and that is the reason that compound $8 \mathrm{a}$ could be trapped by EtOH to give compound 6. Intermediate 8a might form aggregates in the solution via $\pi-\pi$ interaction, very possibly in an anti-parallel manner to minimize the dipolar moment, which also favors the dimerization. In the dimerization, the lone-pair on nitrogen attacks the electron-poor double bond on the $2 \mathrm{H}$-1,3-oxazin-2-one ring. The restoration of the aromaticity of the benzene ring is also the driving force for this step. This is the rate-determining step. The resulting dimer $\mathbf{9}$ is much less strained than the previously proposed four-membered intermediate, hence a more plausible intermediate. It loses two $\mathrm{CO}_{2}$ to afford diazocine 3.

\subsection{Scope and limitations of this reaction}

With the clarified mechanism and optimized conditions in hand, we then investigated the scope of this reaction. A series of dibenzo[ $b f][1,5]$ diazocines with different substituents were synthesized, as shown in Table 2. In all the cases, the reaction in toluene is faster than the reaction in THF. This may be attributed to the non-polar nature of toluene, which favors the anti-parallel
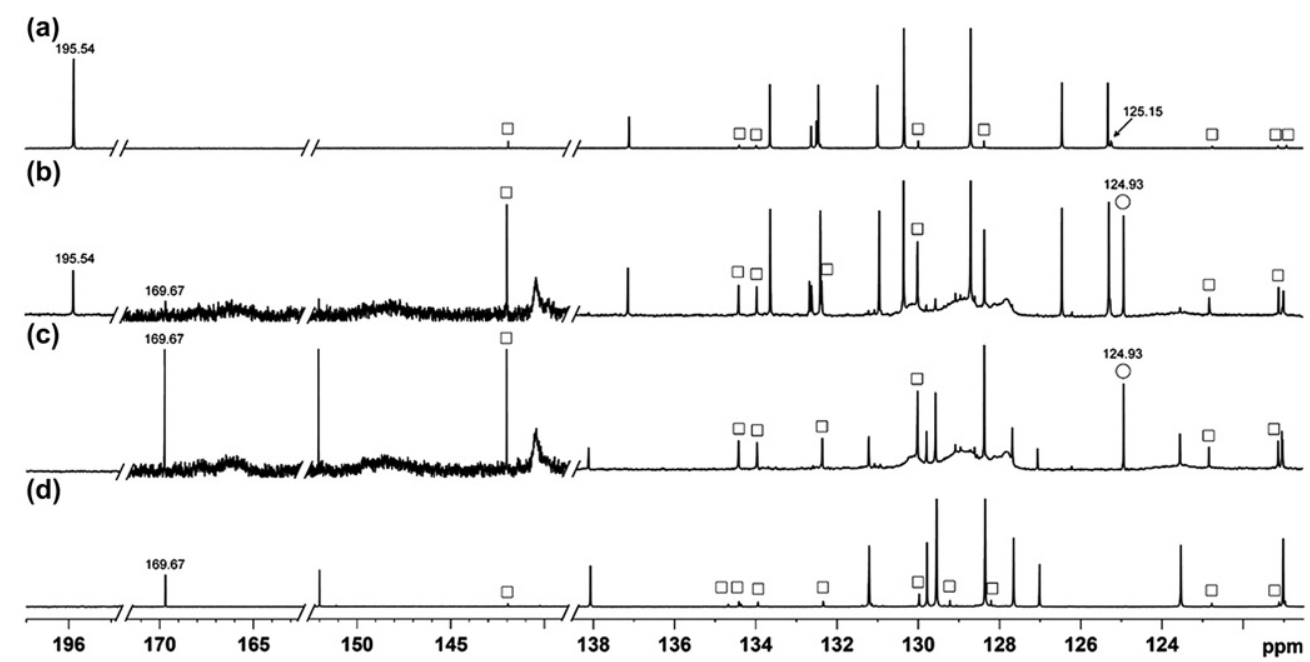

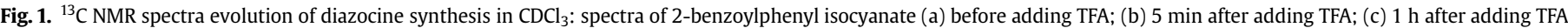
and (d) $24 \mathrm{~h}$ after adding TFA. (b) and (c) was enlarged for a better view. $\square$ stands for the impurities in the reaction, $\bigcirc$ stands for the distinct new peak of the intermediate. 


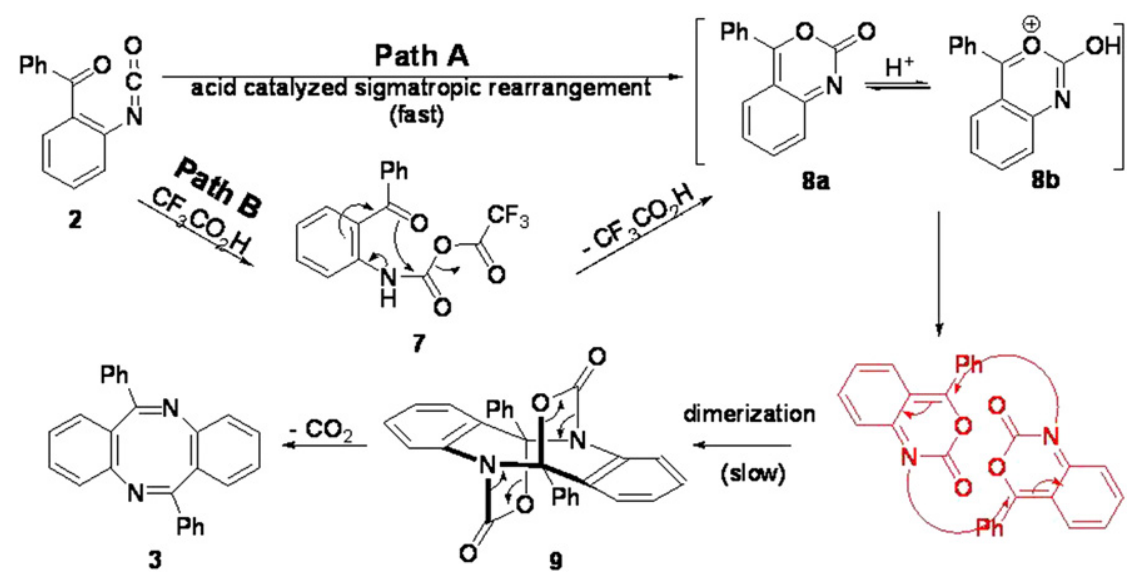

Scheme 4. Revised mechanism for acid-catalyzed diazocine synthesis.

Table 2

Scope of the reaction

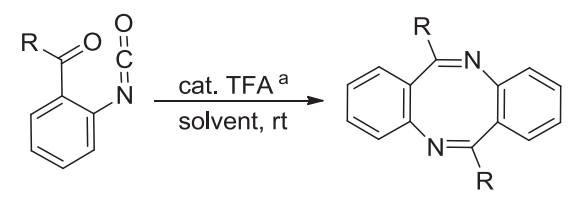

\begin{tabular}{lllll}
\hline Entry & $\mathrm{R}$ & Solvent & Time $(\mathrm{h})$ & Yield $^{\mathrm{c}}(\%)$ \\
\hline 1 & $\mathrm{Ph}$ & $\mathrm{THF} / \mathrm{Tol}$. & $12 / 2$ & $90 / 77$ \\
2 & $p-\mathrm{BrPh}$ & $\mathrm{THF}^{\mathrm{b}} /$ Tol. & $24 / 12$ & $92 / 88$ \\
3 & $p-\mathrm{ClPh}$ & $\mathrm{THF}^{\mathrm{b}} / \mathrm{Tol}$. & $24 / 12$ & $75 / 77$ \\
4 & $m-\mathrm{NO}_{2} \mathrm{Ph}$ & $\mathrm{THF}^{\mathrm{b}} /$ Tol. & $72 / 12$ & $65 / 93$ \\
5 & $p-\mathrm{MePh}$ & $\mathrm{THF}^{\mathrm{b}} /$ Tol. & $24 / 12$ & $82 / 76$ \\
6 & $p-\mathrm{MeOPh}$ & $\mathrm{THF}^{\mathrm{T}} \mathrm{Tol}$. & $24 / 12$ & $88 / 76$ \\
7 & $\mathrm{Thienyl}$ & Tol. & 12 & 80 \\
8 & $t$-Bu & THF/Tol. & $36 / 12$ & $85 / 84$ \\
\hline
\end{tabular}

${ }^{a}$ TFA ( 0.1 equiv) was used as the catalyst unless otherwise stated.

b TFA ( 0.2 equiv) was used.

c Isolated yield calculated using the corresponding azide as the starting material.

aggregation of the intermediate. The substituent on the ketone moiety was not limited to phenyl rings bearing electron-donating or electron-withdrawing groups, heterocyclic substituent, such as thiophene ring also gave a high yield of the diazocine (Table 2, entry 7 ). Even the sterically hindered tert-butyl substituted diazocine was obtained in high yield (Table 2, entry 8 ).

This methodology is not limited to the synthesis of dibenzo[ $b f]$ $[1,5]$ diazocines. Heterocycles bearing a ketone and an isocyanate moiety at adjacent positions also afforded the corresponding diazocines, but harsher conditions are needed. For example, dithieno[1,5]diazocines were synthesized from the corresponding precursors, as shown in Scheme 5. Reflux in pure TFA is needed to drive such reactions, since side reactions (generation of 3-amino-2benzoylthiophene together with some corresponding trifluoroacetamide) would be overwhelming if only a catalytic amount of acid was used. We are not exactly sure why thiophene ring behaves quite differently from benzene ring. One of the possible reason is the lower nucleophilicity of nitrogen atom at 3-position on the thiophene ring, probably due to the electronwithdrawing effect of the sulfur atom on thiophene ring, which makes the dimerization of the intermediate more difficult.

\section{Conclusion}

In summary, we revisited the novel synthetic methodology to prepare diazocines, potential building blocks for conformational change-governed electrochemical actuators. The reaction conditions were further optimized and we found the reaction could occur at room temperature using a catalytic amount of acid. More importantly, we revised the previously proposed mechanism. The diazocine is not formed via an intermolecular [2+2] cyclization between a ketone and an isocyanate moiety, but by a neighboring ketone group participated rearrangement of the isocyanate, followed by an unprecedented dimerization. The new mechanism is strongly supported by experimental evidences.

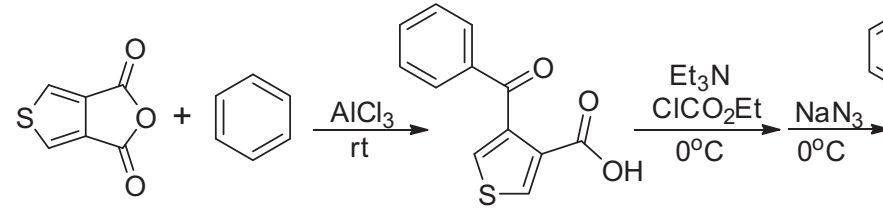

10 a<smiles>NC(=O)c1cscc1C(=O)c1ccccc1</smiles>

11 a
12 a<smiles>c1ccc(/C(=N/c2ccsc2)c2sccc2-c2ccccc2)cc1</smiles> 


\section{Experimental section}

\subsection{General methods}

All glassware was thoroughly oven-dried before use. Chemicals and solvents were either purchased from commercial suppliers or purified by standards techniques. Thin-layer chromatography plates were visualized by exposure to ultraviolet light and/or immersion in a staining solution (phosphomolybdic acid) followed by heating on a hot plate. Flash chromatography was carried out utilizing silica gel 200-300 mesh. Chemical shifts are given in $\delta$ relative to tetramethylsilane (TMS), the coupling constants $J$ are given in hertz. The spectra were recorded in $\mathrm{CDCl}_{3}$ as the solvent at room temperature. TMS served as the internal standard $(\delta=0 \mathrm{ppm})$ for ${ }^{1} \mathrm{H}$ $\mathrm{NMR}$ and $\mathrm{CDCl}_{3}$ was used as the internal standard $(\delta=77.00 \mathrm{ppm})$ for ${ }^{13} \mathrm{C}$ NMR.

\subsection{General methods for the synthesis of diazocines}

Diazocines were synthesized from the corresponding benzoyl azide either in a two-steps manner or in a one-step manner. In the two-steps manner, the benzoyl azide was heated in a toluene under $\mathrm{N}_{2}$ protection to generate the corresponding isocyanate. Toluene was then removed and resulting crude product was characterized and then dissolved a suitable solvent. Catalytic amount of acid was added to facilitate the cyclization. In the one-step manner, benzoyl azide was heated in a suitable solvent to generate the corresponding isocyanate. The reaction mixture was then cooled to room temperature and catalytic amount of acid was added to facilitate the cyclization.

4.2.1. Example for one-step synthesis. 2-Benzoylbenzoyl azide $(1.26 \mathrm{~g}, 5.0 \mathrm{mmol})$ was dissolved in $5 \mathrm{~mL}$ of anhydrous THF and refluxed for $4 \mathrm{~h}$ to afford (2-isocyanatophenyl)(phenyl)methanone without further purification. After cooling down to room temperature, anhydrous TFA ( $37.0 \mu \mathrm{L}, 0.5 \mathrm{mmol}$ ) was added into the solution and stirred for $12 \mathrm{~h}$. The reaction mixture was then neutralized with saturated $\mathrm{Na}_{2} \mathrm{CO}_{3}$ solution and extracted with dichloromethane $(D C M)(3 \times 20 \mathrm{~mL})$. The combined organic layer was dried over anhydrous $\mathrm{MgSO}_{4}$. The solvent was evaporated and the residue was purified by column chromatography on silica gel, using a 3:2 mixture of petroleum ether/dichloromethane as the eluent to give the corresponding product 6,12-diphenyldibenzo[b, $f]$ [1,5]diazocine (3) (0.82 g, $2.3 \mathrm{mmol}, 90 \%$ yield).

4.2.2. Example for two-steps synthesis. 2-Benzoylbenzoyl azide ( $1.26 \mathrm{~g}, 5.0 \mathrm{mmol}$ ) was dissolved in $5 \mathrm{~mL}$ of anhydrous toluene and refluxed for $4 \mathrm{~h}$. After removing the solvent, the yellow oil-like solid was dissolved in $5 \mathrm{~mL}$ of chloroform. Anhydrous TFA $(37.0 \mu \mathrm{L}$, $0.5 \mathrm{mmol}$ ) was added into the solution and stirred for $12 \mathrm{~h}$. The reaction mixture was then neutralized with saturated $\mathrm{Na}_{2} \mathrm{CO}_{3}$ solution and extracted with dichloromethane $(D C M)(3 \times 20 \mathrm{~mL})$. The combined organic layer was dried over anhydrous $\mathrm{MgSO}_{4}$. The solvent was evaporated and the residue was purified by column chromatography on silica gel, using a 3:2 mixture of petroleum ether/dichloromethane as the eluent to give the corresponding product 6,12-diphenyldibenzo[bff][1,5]diazocine (3) $\quad(0.67 \mathrm{~g}$, $1.8 \mathrm{mmol}, 75 \%$ yield).

\subsection{Preparation and characterization of the involved compounds}

4.3.1. (2-Isocyanatophenyl)(phenyl)methanone (2). 2-Benzoylben zoyl azide $(1.26 \mathrm{~g}, 5.0 \mathrm{mmol})$ was dissolved in $5 \mathrm{~mL}$ of anhydrous toluene and refluxed for $4 \mathrm{~h}$. After removing the solvent, almost quantitative (2-isocyanatophenyl)(phenyl)methanone was obtained as yellow oil-like solid. IR ( $\left.\mathrm{KBr}, \mathrm{cm}^{-1}\right)$ : 3063, 2385, 2259, 1656, 1598, 1579, 1511, 1448, 1427, 1317, 1294, 1265, 1153, 1087, $1001,928,806,763,748,696,638,566 ;{ }^{1} \mathrm{H}$ NMR $\left(600 \mathrm{MHz}, \mathrm{CDCl}_{3}\right)$ $\delta 7.22(\mathrm{~d}, J=8.4 \mathrm{~Hz}, 1 \mathrm{H}), 7.29(\mathrm{t}, J=7.8 \mathrm{~Hz}, 1 \mathrm{H}), 7.48(\mathrm{~d}, J=7.8 \mathrm{~Hz}, 1 \mathrm{H})$, $7.50(\mathrm{t}, J=7.8 \mathrm{~Hz}, 3 \mathrm{H}), 7.63(\mathrm{t}, J=7.2 \mathrm{~Hz}, 1 \mathrm{H}), 7.83(\mathrm{~d}, J=7.2 \mathrm{~Hz}, 2 \mathrm{H})$; ${ }^{13} \mathrm{C}$ NMR $\left(150 \mathrm{MHz}, \mathrm{CDCl}_{3}\right) \delta 125.1,125.2,126.4,128.6,130.2,130.9$, $132.3,132.4,132.5,133.5,137.0,195.8$.

4.3.2. 6,12-Bisphenyldibenzo[b,f][1,5]diazocine (3). Compound 3 was synthesized by the one-step manner in THF. Yield: $90 \%$. Yellow solid. Mp: $226-227{ }^{\circ} \mathrm{C}$. IR $\left(\mathrm{KBr}, \mathrm{cm}^{-1}\right)$ : $3063,3023,1622$, $1592,1574,1477,1448,1318,1304,1222,1213,1148,1096,961,909$, $835,777,671,649,605,574,522 ;{ }^{1} \mathrm{H}$ NMR $\left(600 \mathrm{MHz}, \mathrm{CDCl}_{3}\right) \delta 7.00$ $(\mathrm{m}, 6 \mathrm{H}), 7.31(\mathrm{~m}, 6 \mathrm{H}), 7.40(\mathrm{t}, J=7.8 \mathrm{~Hz}, 2 \mathrm{H}), 7.76(\mathrm{~d}, J=8.4 \mathrm{~Hz}, 4 \mathrm{H})$; ${ }^{13} \mathrm{C}$ NMR $\left(150 \mathrm{MHz}, \mathrm{CDCl}_{3}\right) \delta 120.9,123.4,126.9,127.5,128.2$, 129.4, 129.6, 131.0, 137.9, 151.8, 169.5. HRMS (EI): calcd for $\left[\mathrm{C}_{26} \mathrm{H}_{18} \mathrm{~N}_{2}\right]$ : 358.1470, found: 358.1469.

4.3.3. 6,12-Bis(4-bromophenyl)dibenzo[b,f][1,5]diazocine (Table 2, entry 2). This compound was synthesized by the one-step manner in THF. Yield: 92\%. Yellow solid. Mp 236-237 ${ }^{\circ} \mathrm{C}$. IR ( $\mathrm{KBr}$, $\left.\mathrm{cm}^{-1}\right)$ : 3059, 3018, 1618, 1583, 1560, 1475, 1395, 1308, 1069, 1009, 959, 907, 841, 769, 728, 656, 471; ${ }^{1} \mathrm{H}$ NMR $\left(600 \mathrm{MHz}, \mathrm{CDCl}_{3}\right) \delta 6.93$ (d, $J=7.8 \mathrm{~Hz}, 2 \mathrm{H}), 7.02$ (t, $J=7.8 \mathrm{~Hz}, 4 \mathrm{H}), 7.32(\mathrm{t}, J=7.8 \mathrm{~Hz}, 2 \mathrm{H}), 7.47$ $(\mathrm{d}, J=8.4 \mathrm{~Hz}, 4 \mathrm{H}), 7.61(\mathrm{~d}, J=8.4 \mathrm{~Hz}, 4 \mathrm{H}) ;{ }^{13} \mathrm{C} \mathrm{NMR}\left(150 \mathrm{MHz}, \mathrm{CDCl}_{3}\right)$ $\delta$ 120.9, 123.6, 126.0, 126.2, 127.3, 129.9, 130.9, 131.4, 136.8, 151.7, 168.6. HRMS (EI): calcd for $\left[\mathrm{C}_{26} \mathrm{H}_{16} \mathrm{Br}_{2} \mathrm{~N}_{2}\right]$ : 515.9660, found: 515.9653.

4.3.4. 6,12-Bis(4-chlorophenyl)dibenzo[b,f][1,5]diazocine (Table 2, entry 3). This compound was synthesized by the one-step manner in THF. Yield: $75 \%$. Yellow solid. Mp $217-218^{\circ} \mathrm{C}$. IR $\left(\mathrm{KBr}, \mathrm{Cm}^{-1}\right)$ : 3064, 3018, 1618, 1587, 1566, 1476, 1400, 1308, 1090, 1013, 960, 907, 842, 759, 731, 659, 531; ${ }^{1} \mathrm{H}$ NMR (600 MHz, $\left.\mathrm{CDCl}_{3}\right) \delta 6.94(\mathrm{~d}$, $J=7.8 \mathrm{~Hz}, 2 \mathrm{H}), 7.03(\mathrm{t}, J=7.8 \mathrm{~Hz}, 4 \mathrm{H}), 7.32(\mathrm{~m}, 6 \mathrm{H}), 7.69(\mathrm{~d}, J=8.4 \mathrm{~Hz}$, $4 \mathrm{H}) ;{ }^{13} \mathrm{C} \mathrm{NMR}\left(150 \mathrm{MHz} \mathrm{CDCl}_{3}\right) \delta 120.9,123.6,126.3,127.4,128.4$, 129.9, 130.7, 136.3, 137.4, 151.7, 168.5. HRMS (EI): calcd for $\left[\mathrm{C}_{26} \mathrm{H}_{16} \mathrm{Cl}_{2} \mathrm{~N}_{2}\right.$ ]: 428.0661 , found: 428.0640 .

4.3.5. 6,12-Bis(3-nitrophenyl)dibenzo[b,f][1,5]diazocine (Table 2, entry 4). This compound was synthesized by the one-step manner in THF. Yield: $65 \%$. Yellow solid. Mp $190{ }^{\circ} \mathrm{C}$. IR $\left(\mathrm{KBr}, \mathrm{cm}^{-1}\right)$ : 3082 , 1625, 1611, 1530, 1478, 1400, 1349, 1313, 1088, 988, 909, 831, 773, 733, 695, 679; ${ }^{1} \mathrm{H}$ NMR $\left(600 \mathrm{MHz}, \mathrm{CDCl}_{3}\right) \delta 6.99(\mathrm{~m}, 2 \mathrm{H}), 7.10(\mathrm{~m}$, $4 \mathrm{H}), 7.40(\mathrm{~m}, 2 \mathrm{H}), 7.53(\mathrm{t}, J=7.8 \mathrm{~Hz}, 2 \mathrm{H}), 8.02(\mathrm{~d}, J=8.4 \mathrm{~Hz}, 2 \mathrm{H})$, $8.27(\mathrm{~m}, 2 \mathrm{H}), 8.69(\mathrm{t}, J=1.8 \mathrm{~Hz}, 2 \mathrm{H}) ;{ }^{13} \mathrm{C} \mathrm{NMR}\left(150 \mathrm{MHz}, \mathrm{CDCl}_{3}\right)$ $\delta$ 121.2, 123.9, 124.4, 125.2, 127.2, 125.6, 129.4, 130.5, 135.1, 139.4, 148.4, 151.1, 167.4. HRMS (EI): calcd for $\left[\mathrm{C}_{26} \mathrm{H}_{16} \mathrm{~N}_{4} \mathrm{O}_{4}\right]$ : 448.1172 , found: 448.1174 .

4.3.6. 6,12-Bis(4-methylphenyl)dibenzo[b,f][1,5]diazocine (Table 2, entry 5). This compound was synthesized by the one-step manner in THF. Yield: 82\%. Yellow solid. Mp 190-191 ${ }^{\circ} \mathrm{C}$. IR $\left(\mathrm{KBr}, \mathrm{cm}^{-1}\right)$ : 3059, 3024, 2913, 1622, 1604, 1589, 1567, 1477, 1314, 960, 840, 827, 769, 728, 667; ${ }^{1} \mathrm{H}$ NMR $\left(600 \mathrm{MHz}, \mathrm{CDCl}_{3}\right)$ $\delta 2.36(\mathrm{~s}, 6 \mathrm{H}), 7.00(\mathrm{~m}, 6 \mathrm{H}), 7.15(\mathrm{~d}, J=8.4 \mathrm{~Hz}, 4 \mathrm{H}), 7.31(\mathrm{t}$, $J=7.8 \mathrm{~Hz}, 2 \mathrm{H}), 7.66(\mathrm{~d}, J=8.4 \mathrm{~Hz}, 4 \mathrm{H}) ;{ }^{13} \mathrm{C} \mathrm{NMR}\left(150 \mathrm{MHz}, \mathrm{CDCl}_{3}\right)$ o 21.4, 120.9, 123.1, 127.2, 127.5, 128.9, 129.4, 129.5, 131.4, 135.4, 152.0, 169.4. HRMS (EI): calcd for $\left[\mathrm{C}_{28} \mathrm{H}_{22} \mathrm{~N}_{2}\right]$ : 386.1783 , found: 386.1778 .

4.3.7. 6,12-Bis(4-methoxyphenyl)dibenzo[b,f][1,5]diazocine (Table 2, entry 6 ). This compound was synthesized by the one-step manner in THF. Yield: $88 \%$. Yellow solid. Mp 204-205 ${ }^{\circ} \mathrm{C}$. IR $\left(\mathrm{KBr}, \mathrm{cm}^{-1}\right)$ : 3062, 3009, 2958, 2930, 2835, 1618, 1597, 1570, 1510, 1476, 1310, $1254,1174,1147,1032,961,909,843,769,733,618,596,555 ;{ }^{1} \mathrm{H}$ 
NMR (600 MHz, $\left.\mathrm{CDCl}_{3}\right) \delta 3.80(\mathrm{~s}, 6 \mathrm{H}), 6.84(\mathrm{~d}, J=9 \mathrm{~Hz}, 4 \mathrm{H}), 6.98(\mathrm{~m}$, $6 \mathrm{H}), 7.28(\mathrm{~m}, 2 \mathrm{H}), 7.71(\mathrm{~d}, J=9 \mathrm{~Hz}, 4 \mathrm{H}) ;{ }^{13} \mathrm{C}$ NMR $\left(150 \mathrm{MHz}, \mathrm{CDCl}_{3}\right)$ $\delta$ 55.4, 113.5, 121.0, 123.0, 127.2, 127.5, 129.4, 130.7, 131.1, 152.1, 162.0, 168.8. HRMS (EI): calcd for $\left[\mathrm{C}_{28} \mathrm{H}_{22} \mathrm{~N}_{2} \mathrm{O}_{2}\right]$ : 418.1681, found: 418.1680 .

4.3.8. 6,12-Bis(thiophen-2-yl)dibenzo[b,f][1,5]diazocine (Table 2, entry 7). This compound was synthesized by the one-step manner in toluene. Yield: $80 \%$. Yellow solid. $\mathrm{Mp} 213-214{ }^{\circ} \mathrm{C}$. IR $\left(\mathrm{KBr}, \mathrm{cm}^{-1}\right)$ : 3068, 2970, 1738, 1713, 1604, 1477, 1422, 1356, 1309, 1206, 1048, 923, 894, 846, 770, 713; ${ }^{1} \mathrm{H}$ NMR $\left(600 \mathrm{MHz}, \mathrm{CDCl}_{3}\right) \delta 6.99(\mathrm{t}$, $J=3.6 \mathrm{~Hz}, 2 \mathrm{H}), 7.04(\mathrm{~m}, 6 \mathrm{H}), 7.28(\mathrm{~d}, J=7.8 \mathrm{~Hz}, 2 \mathrm{H}), 7.32(\mathrm{t}, J=7.8 \mathrm{~Hz}$, $2 \mathrm{H}), 7.48(\mathrm{~d}, J=5.1 \mathrm{~Hz}, 2 \mathrm{H}) ;{ }^{3} \mathrm{C}$ NMR $\left(150 \mathrm{MHz}, \mathrm{CDCl}_{3}\right) \delta$ 121.8, 123.5, 126.2, 127.6, 127.8, 129.9, 131.1, 133.1, 144.7, 150.6, 163.9. HRMS (ESI): calcd for $\left[\mathrm{C}_{22} \mathrm{H}_{14} \mathrm{~N}_{2} \mathrm{~S}_{2}+\mathrm{H}\right]^{+}$: 371.0677 , found: 371.0682 .

4.3.9. 6,12-Bis-tert-butyldibenzo[b,f][1,5]diazocine (Table 2, entry $8)$. This compound was synthesized using the one-step manner. Yield: $85 \%$. Yellow solid. Mp $130-131^{\circ} \mathrm{C}$. IR $\left(\mathrm{KBr}, \mathrm{cm}^{-1}\right)$ : 3063, 2967, 2928, 2868, 1631, 1594, 1474, 1444, 1391, 1362, 1278, 1237, 1198, 1156, 1114, 1030, 991, 937, 840, 810, 765, 753, 731, 698, 676, 598, 523, 486; ${ }^{1} \mathrm{H}$ NMR (600 MHz, $\left.\mathrm{CDCl}_{3}\right) \delta 1.29(\mathrm{~s}, 18 \mathrm{H}), 6.78(\mathrm{~d}$, $J=7.2 \mathrm{~Hz}, 2 \mathrm{H}), 6.87(\mathrm{t}, J=7.2 \mathrm{~Hz}, 2 \mathrm{H}), 6.90$ (d, $J=7.2 \mathrm{~Hz}, 2 \mathrm{H}), 7.12(\mathrm{t}$, $J=7.2 \mathrm{~Hz}, 2 \mathrm{H}) ;{ }^{13} \mathrm{C}$ NMR $\left(150 \mathrm{MHz}, \mathrm{CDCl}_{3}\right) \delta 28.5,40.5,119.4,122.4$, $125.3,127.5,128.4,151.1,181.0$.

4.3.10. 4-Ethoxy-4-phenyl-1H-benzo[d][1,3]oxazin-2(4H)-one (6). 2-Benzoylbenzoyl azide ( $1.26 \mathrm{~g}, 5.0 \mathrm{mmol}$ ) was dissolved in $5 \mathrm{~mL}$ of anhydrous toluene and refluxed for $4 \mathrm{~h}$. After removing the solvent, the yellow oil-like solid was dissolved in $5 \mathrm{~mL}$ of chloroform. Anhydrous TFA ( $37.0 \mu \mathrm{L}, 0.5 \mathrm{mmol}$ ) was added into the solution and stirred for $45 \mathrm{~min}$. Then $5 \mathrm{~mL}$ of anhydrous ethanol was added into the mixture to quench the reaction. The solvent was evaporated and the residue was purified by column chromatography on silica gel, using dichloromethane and a 1:1 mixture of ethyl acetate/dichloromethane successively as the eluent to afford $\mathbf{6}$ as a yellow solid $(0.57 \mathrm{~g}, 2.1 \mathrm{mmol}, 42 \%$ yield). Yellow solid. Mp 156-157 ${ }^{\circ} \mathrm{C}$. IR $\left(\mathrm{KBr}, \mathrm{cm}^{-1}\right)$ : 3249, 2980, 2927, 1713, 1603, 1497, 1449, 1353, 1276, 1254, 1207, 1132, 1094, 1072, 1001, 971, 913, 749, 699, 653, 458; ${ }^{1} \mathrm{H}$ NMR $\left(600 \mathrm{MHz}, \mathrm{CDCl}_{3}\right) \delta 1.27(\mathrm{t}, J=6.6 \mathrm{~Hz}, 3 \mathrm{H})$, $3.70(\mathrm{~m}, 2 \mathrm{H}), 6.95$ (d, J=7.8 Hz, 1H), $7.04(\mathrm{~m}, 2 \mathrm{H}), 7.30$ (t, $J=7.8 \mathrm{~Hz}$, $1 \mathrm{H}), 7.40(\mathrm{~m}, 3 \mathrm{H}), 7.53(\mathrm{~d}, J=6.6 \mathrm{~Hz}, 2 \mathrm{H}), 9.27(\mathrm{~s}, 1 \mathrm{H}) ;{ }^{13} \mathrm{C} \mathrm{NMR}$ $\left(150 \mathrm{MHz}, \mathrm{CDCl}_{3}\right) \delta 15.2,60.4,107.3,114.7,121.1,123.5,126.6,126.7$, 128.4, 129.1, 130.2, 134.8, 139.0, 152.0. MS (EI): calcd for $\left[\mathrm{C}_{16} \mathrm{H}_{15} \mathrm{NO}_{3}+\mathrm{H}\right]^{+}$: 270.1125, found: 270.1123 .

4.3.11. 4-Benzoylthiophene-3-carboxylic acid (10a). A mixture of thieno[3,4-c]furan-1,3-dione ${ }^{24}(1.0 \mathrm{~g}, 6.4 \mathrm{mmol})$, benzene $(10.0 \mathrm{~mL}$, $110 \mathrm{mmol})$, and anhydrous $\mathrm{AlCl}_{3}(1.7 \mathrm{~g}, 12.8 \mathrm{mmol})$ was stirred at room temperature for $5 \mathrm{~h}$. The reaction mixture was then quenched with $100 \mathrm{~mL}$ of saturated $\mathrm{Na}_{2} \mathrm{CO}_{3}$ solution and extracted with $\mathrm{CH}_{2} \mathrm{Cl}_{2}(3 \times 100 \mathrm{~mL})$. The water layer was separated, acidified to $\mathrm{pH}=1$ by $3 \mathrm{M} \mathrm{HCl}$ solution, and extracted with $\mathrm{CH}_{2} \mathrm{Cl}_{2}(3 \times 100 \mathrm{~mL})$. The organic layers were combined, dried over anhydrous $\mathrm{MgSO}_{4}$, and filtered to remove the solids thereafter. The filtrate was evaporated at reduced pressure to afford the corresponding product in $70 \%$ yield.

4.3.12. 4-Benzoylthiophene-3-carbonyl azide (11a). To a $10 \mathrm{~mL}$ of THF solution containing 4-benzoylthiophene-3-carboxylic acid $(0.9 \mathrm{~g}, 3.9 \mathrm{mmol})$ at $0{ }^{\circ} \mathrm{C}$, was added dropwise triethylamine $(0.6 \mathrm{~mL}, 4.3 \mathrm{mmol})$, followed by the dropwise addition of ethyl chloroformate $(0.4 \mathrm{~mL}, 4.3 \mathrm{mmol})$. After $30 \mathrm{~min}$, a solution of sodium azide $(0.28 \mathrm{~g}, 4.3 \mathrm{mmol})$ in water $(7 \mathrm{~mL})$ was added dropwise, and the mixture was stirred for $30 \mathrm{~min}$. THF was then removed by evaporation, and the remaining aqueous phase was extracted with
$\mathrm{CH}_{2} \mathrm{Cl}_{2}(3 \times 30 \mathrm{~mL})$. The organic layers were combined, washed with brine, and dried over anhydrous $\mathrm{MgSO}_{4}$. The solvent was evaporated at reduced pressure and the resulting mixture was directly purified by column chromatography on silica gel, using a 5:1 mixture of petroleum ether/ethyl acetate as the eluent to give 4benzoylthiophene-3-carbonyl azide $(0.8 \mathrm{~g}, 3.1 \mathrm{mmol}, 80 \%$ yield $)$. $\mathrm{IR}\left(\mathrm{KBr}, \mathrm{cm}^{-1}\right)$ : 3103, 3059, 2261, 2163, 2136, 1686, 1596, 1578, 1449, $1437,1386,1312,1262,1216,1175,1025,976,897,832,791,774,702$, 636, 563; ${ }^{1} \mathrm{H}$ NMR $\left(600 \mathrm{MHz}, \mathrm{CDCl}_{3}\right) \delta 7.47(\mathrm{~d}, J=7.2 \mathrm{~Hz}, 2 \mathrm{H}), 7.53$ (d, $J=3 \mathrm{~Hz}, 1 \mathrm{H}), 7.59(\mathrm{t}, J=7.2 \mathrm{~Hz}, 1 \mathrm{H}), 7.8(\mathrm{~d}, J=7.2 \mathrm{~Hz}, 2 \mathrm{H}), 8.21$ (d, $J=3 \mathrm{~Hz}, 1 \mathrm{H}) ;{ }^{13} \mathrm{C}$ NMR $\left(150 \mathrm{MHz}, \mathrm{CDCl}_{3}\right) \delta 128.6,128.8,129.5,133.6$, 135.4, 137.2, 141.4, 166.7, 191.7.

4.3.13. 5,10-Diphenyldithieno[3,4-b:3',4'-f][1,5]diazocine (12a). This compound was synthesized by heating the corresponding precursor in TFA at $80{ }^{\circ} \mathrm{C}$ for $12 \mathrm{~h}$. Yield: $40 \%$. Yellow solid. Mp 85-86 ${ }^{\circ} \mathrm{C}$. IR $\left(\mathrm{KBr}, \mathrm{cm}^{-1}\right)$ : 3099, 3062, 2242, 2220, 1723, 1615, 1594, $1577,1525,1488,1428,1365,1270,1185,1144,1071,1027,948,908$, 861, 766, 699, 641, 592, 446; ${ }^{1} \mathrm{H}$ NMR $\left(600 \mathrm{MHz}, \mathrm{CDCl}_{3}\right) \delta 6.83(\mathrm{~d}$, $J=3.6 \mathrm{~Hz}, 2 \mathrm{H}), 7.06$ (d, $J=3.6 \mathrm{~Hz}, 2 \mathrm{H}), 7.39$ (t, $J=7.2 \mathrm{~Hz}, 4 \mathrm{H}), 7.47$ (t, $J=7.2 \mathrm{~Hz}, 2 \mathrm{H}), 7.87$ (d, $J=7.2 \mathrm{~Hz}, 4 \mathrm{H}) ;{ }^{13} \mathrm{C}$ NMR $\left(150 \mathrm{MHz}, \mathrm{CDCl}_{3}\right)$ $\delta 116.9,125.0,128.7,129.3,130.7,131.3,138.4,149.9,166.9$.

4.3.14. 2-Benzoylthiophene-3-carboxylic acid (10b). To a solution of thiophene-3-carboxylic acid $(5.0 \mathrm{~g}, 39 \mathrm{mmol})$ in THF $(200 \mathrm{~mL})$ at $0{ }^{\circ} \mathrm{C}$, was added dropwise $50 \mathrm{~mL}$ of THF solution containing $86 \mathrm{mmol}$ fresh-prepared LDA. Benzaldehyde $(4.4 \mathrm{~mL}, 43 \mathrm{mmol})$ was then added to the mixture, and the mixture was warmed up to room temperature and stirred for $2 \mathrm{~h}$. The reaction was quenched by the addition of ice-water $(100 \mathrm{~mL})$, and the mixture was concentrated under reduced pressure and washed with AcOEt $(2 \times 30 \mathrm{~mL})$. To the residual aqueous layer, was added $\mathrm{KMnO}_{4}(12 \mathrm{~g}$, $78 \mathrm{mmol}$ ) in portions, and the mixture was stirred for $2 \mathrm{~h}$ at $60^{\circ} \mathrm{C}$. It was then filtrated and washed with hot water, and the resulting filtrate was acidified to $\mathrm{pH}=3$ using $3 \mathrm{M}$ aqueous $\mathrm{HCl}$, and extracted with dichloromethane $(3 \times 100 \mathrm{~mL})$. The organic layers were combined, washed with brine, and dried over anhydrous $\mathrm{MgSO}_{4}$. The solvent was evaporated at reduced pressure to give 2benzoylthiophene-3-carboxylic acid ( $8.2 \mathrm{~g}$ crude), which was used directly in next step without purification.

4.3.15. 2-Benzoylthiophene-3-carbonyl azide (11b). To a $50 \mathrm{~mL}$ of THF solution containing crude 2-benzoylthiophene-3-carboxylic acid $(2.3 \mathrm{~g}, 10 \mathrm{mmol})$ at $0{ }^{\circ} \mathrm{C}$, was dropwise added triethylamine $(1.6 \mathrm{~mL}, 11 \mathrm{mmol})$, followed by the dropwise addition of ethyl chloroformate $(1.1 \mathrm{~mL}, 11 \mathrm{mmol})$. After $2 \mathrm{~h}$, a solution of sodium azide $(0.72 \mathrm{~g}, 11 \mathrm{mmol})$ in water $(30.0 \mathrm{~mL})$ was added dropwise, and the mixture was stirred for $1 \mathrm{~h}$. THF was then removed by evaporation, and the remaining aqueous phase was extracted with $\mathrm{CH}_{2} \mathrm{Cl}_{2}(3 \times 30 \mathrm{~mL})$. The organic layers were combined, washed with brine, and dried over anhydrous $\mathrm{MgSO}_{4}$. The solvent was evaporated at reduced pressure and the resulting mixture was directly purified by column chromatography on silica gel, using a 5:1 mixture of petroleum ether/ethyl acetate as the eluent to give 2-benzoylthiophene-3-carbonyl azide $\left(1.7 \mathrm{~g}, 6.6 \mathrm{mmol}, 66 \%\right.$ yield). IR $\left(\mathrm{KBr}, \mathrm{cm}^{-1}\right): 3110,2340$, 2245, 2143, 1685, 1580, 1519, 1449, 1382, 1369, 1265, 1234, 1176, 1137, 1070, 1040, 899, 845, 802, 710, 689, 658, 561; ${ }^{1} \mathrm{H}$ NMR $\left(600 \mathrm{MHz}, \mathrm{CDCl}_{3}\right) \delta 7.51(\mathrm{~m}, 4 \mathrm{H}), 7.63(\mathrm{t}, J=7.2 \mathrm{~Hz}, 1 \mathrm{H}), 7.85(\mathrm{~d}$, $J=7.2 \mathrm{~Hz}, 2 \mathrm{H}) ;{ }^{13} \mathrm{C} \mathrm{NMR}\left(150 \mathrm{MHz}, \mathrm{CDCl}_{3}\right) \delta 127.6,128.4,128.8$, $129.5,133.5,133.9,137.2,147.4,167.3,189.6$.

4.3.16. 5,10-Diphenyldithieno[3,2-b:3',2'-f][1,5]diazocine (12b). This compound was synthesized by heating the corresponding precursor in TFA at $80{ }^{\circ} \mathrm{C}$ for $12 \mathrm{~h}$. Yield: 38\%. Yellow solid. Mp 160-161 ${ }^{\circ} \mathrm{C}$. IR $\left(\mathrm{KBr}, \mathrm{cm}^{-1}\right)$ : 3063, 2917, 2227, 1724, 1606, 1593, 
1523, 1488, 1447, 1361, 1278, 1200, 1176, 1027, 998, 933, 909, 834, 756, 690, 659, 606, 455; ${ }^{1} \mathrm{H}$ NMR $\left(600 \mathrm{MHz}, \mathrm{CDCl}_{3}\right) \delta 6.88(\mathrm{~d}$, $J=7.2 \mathrm{~Hz}, 2 \mathrm{H}), 7.4(\mathrm{t}, J=7.2 \mathrm{~Hz}, 4 \mathrm{H}), 7.49(\mathrm{~d}, J=4.8 \mathrm{~Hz}, 2 \mathrm{H}), 7.48$ (d, $J=7.2 \mathrm{~Hz}, 2 \mathrm{H}), 7.84(\mathrm{~d}, J=4.8 \mathrm{~Hz}, 4 \mathrm{H}) ;{ }^{13} \mathrm{C} \mathrm{NMR}\left(150 \mathrm{MHz}, \mathrm{CDCl}_{3}\right)$ $\delta$ 119.3, 124.4, 128.1, 128.3, 129.7, 131.4, 138.8, 153.8, 165.6.

Preparation of the precursor toward tert-butyl substituted diazocine was shown in Scheme 6.
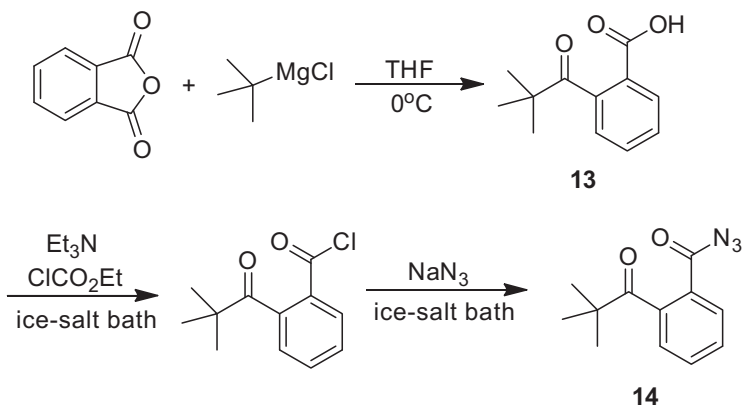

Scheme 6. Preparation of the precursor toward tert-butyl substituted diazocine.

4.3.17. 2-Pivaloylbenzoic acid (13). To a $20.0 \mathrm{~mL}$ of anhydrous THF solution containing phthalic anhydride $(3.0 \mathrm{~g}, 20 \mathrm{mmol})$ at $0{ }^{\circ} \mathrm{C}$, was added dropwise the fresh-prepared tert-butylmagnesium chloride/THF (40 mmol) solution. The mixture was then gradually warmed up to room temperature and stirred overnight. Then $5.0 \mathrm{~mL}$ of saturated $\mathrm{NH}_{4} \mathrm{Cl}$ solution was added slowly into the mixture at $0^{\circ} \mathrm{C}$ and the $\mathrm{pH}$ value of the mixture was adjusted to two using $1 \mathrm{M} \mathrm{HCl}$ solution. After extraction with $\mathrm{Et}_{2} \mathrm{O}$ and removal of the solvent, $3.7 \mathrm{~g}$ of yellow solid was obtained without further purification.

4.3.18. 2-Pivaloylbenzoyl azide (14). To a $50.0 \mathrm{~mL}$ of THF solution containing crude 2-pivaloylbenzoic acid $(2.1 \mathrm{~g}, 10 \mathrm{mmol})$ immersed in an ice-salt bath, was added dropwise triethylamine $(1.6 \mathrm{~mL}$, $11 \mathrm{mmol}$ ), followed by the dropwise addition of ethyl chloroformate $(1.1 \mathrm{~mL}, 11 \mathrm{mmol})$. After $30 \mathrm{~min}$, a solution of sodium azide $(0.72 \mathrm{~g}, 11 \mathrm{mmol})$ in water $(30.0 \mathrm{~mL})$ was added dropwise, and the mixture was stirred for $30 \mathrm{~min}$. THF was then removed by evaporation, and the remaining aqueous phase was extracted with dichloromethane $(3 \times 30 \mathrm{~mL})$. The organic layers were combined, washed with brine, and dried over anhydrous $\mathrm{MgSO}_{4}$. The solvent was evaporated at reduced pressure and the resulting mixture was directly purified by column chromatography on silica gel, using a 3:1 mixture of petroleum ether/dichloromethane as the eluent to give 2-pivaloylbenzoyl azide (1.6 g, $7 \mathrm{mmol}, 70 \%$ yield). IR ( $\mathrm{KBr}$, $\left.\mathrm{cm}^{-1}\right)$ : 2968, 2177, 2136, 1778, 1694, 1596, 1572, 1479, 1392, 1363, $1246,1187,1131,990,967,956,905,864,772,710,691,659,566 ;{ }^{1} \mathrm{H}$ $\operatorname{NMR}\left(600 \mathrm{MHz}, \mathrm{CDCl}_{3}\right) \delta 1.28(\mathrm{~s}, 9 \mathrm{H}), 7.24(\mathrm{~d}, J=7.2 \mathrm{~Hz}, 1 \mathrm{H}), 7.47(\mathrm{t}$, $J=7.8 \mathrm{~Hz}, 1 \mathrm{H}), 7.64(\mathrm{t}, J=7.8 \mathrm{~Hz}, 1 \mathrm{H}), 7.99(\mathrm{~d}, J=8.4 \mathrm{~Hz}, 1 \mathrm{H}) ;{ }^{13} \mathrm{C} \mathrm{NMR}$ $\left(150 \mathrm{MHz}, \mathrm{CDCl}_{3}\right) \delta 27.3,45.0,125.7,127.6,128.6,130.3,133.9,144.2$, 172.0, 214.2.

\subsection{Real-time ${ }^{13} \mathrm{C}$ NMR analysis of the reaction}

(2-Isocyanatophenyl)(phenyl) methanone $2(50 \mathrm{mg})$ was dissolved in $0.5 \mathrm{~mL}$ of $\mathrm{CDCl}_{3}$ in an NMR tube and characterized by ${ }^{13} \mathrm{C}$ NMR. Then 0.1 equiv TFA was added into the tube and mixed well. The ${ }^{13} \mathrm{C}$ NMR spectra of the mixture were collected every 5 min for the first hour and every $10 \mathrm{~min}$ for the next hour. The ${ }^{13} \mathrm{C}$ NMR spectra of the mixture at $8 \mathrm{~h}$ and $24 \mathrm{~h}$ after adding TFA were also collected.

\section{Acknowledgements}

We appreciate the financial support from NSFC (21174157) and '100 Talents' program from Chinese Academy of Sciences and Shandong Natural Sciences Foundation (Y2008B03 and BS2009CL026). We also thank Ms. Ying Yang and Dr. Shaohua Huang for NMR technique supports.

\section{Supplementary data}

Supplementary data related to this article is available online at http://dx.doi.org/10.1016/j.tet.2012.09.050.

\section{References and notes}

1. Marsella, M. J. Acc. Chem. Res. 2002, 35, 944-951.

2. Marsella, M. J.; Reid, R. J. Macromolecules 1999, 32, 5982-5984.

3. Marsella, M. J.; Reid, R. J.; Estassi, S.; Wang, L. S. J. Am. Chem. Soc. 2002, 124, 12507-12510.

4. Song, C.; Swager, T. M. J. Org. Chem. 2010, 75, 999-1005.

5. Song, C.; Walker, D. B.; Swager, T. M. Macromolecules 2010, 43, 5233-5237.

6. Schnieders, C.; Huber, W.; Lex, J.; Müllen, K. Angew. Chem., Int. Ed. Engl. 1985, 24, 576-577.

7. Suga, T.; Wi, S.; Long, T. E. Macromolecules 2009, 42, 1526-1532.

8. Hoppin, C.; Bates, R. B.; Contreras, C. G.; Somogyi, A.; Streeter, M. J.; Hall, H. K. Polym. Bull. 2009, 63, 509-515.

9. Valík, M.; Strongin, R. M.; Král, V. Supramol. Chem. 2005, 17, 347-367.

10. Metlesics, W.; Resnick, T.; Silverman, G.; Tavares, R.; Sternbach, L. H. J. Med. Chem. 1966, 9, 633-634.

11. Isagawa, K.; Ishiwaka, T.; Kawai, M.; Fushizaki, Y. Bull. Chem. Soc. Jpn. 1969, 42, 2066-2068.

12. Boruah, R. C.; Sandhu, J. S. J. Heterocycl. Chem. 1988, 25, 459-462.

13. Scheifele, H. J.; Detar, D. F. Org. Synth. 1952, 32, 8-13.

14. Acharya, B. P.; Rao, R. Y. Synthesis 1986, 1986, 324-326.

15. Acharya, B. P.; Rao, R. Y. J. Chem. Res. 1987, 4, 1001-1035.

16. Jung, D.-I.; Song, J.-H.; Lee, E.-J.; Kim, Y.-Y.; Lee, D.-H.; Lee, Y.-G.; Hahn, J.-T. Tetrahedron Lett. 2009, 50, 5805-5807.

17. Ohashi, M.; Ezaki, A.; Yonezawa, T. J. Chem. Soc., Chem. Commun. 1974, 617.

18. Rees, C. W.; Storr, R. C.; Whittle, P. J. J. Chem. Soc., Chem. Commun. 1976, 411-412.

19. Wang, X.; Li, J.; Zhao, N.; Wan, X. Org. Lett. 2011, 13, 709-711.

20. Weiner, M. J. Org. Chem. 1960, 25, 2245-2246.

21. Shozda, R. J. J. Org. Chem. 1967, 32, 2960-2964.

22. Yamamoto, I.; Tabo, Y.; Gotoh, H.; Minami, T.; Ohshiro, Y.; Agawa, T. Tetrahedron Lett. 1971, 12, 2295-2296.

23. Arnold, R. G.; Nelson, J. A.; Verbanc, J. J. Chem. Rev. 1957, 57, 47-76.

24. Nielsen, C. B.; Bjornholm, T. Org. Lett. 2004, 6, 3381-3384. 